\title{
Keçiboynuzu Unu İlavesinin Kakaolu Kekin Fiziksel, Duyusal ve Tekstürel Özelliklerine Etkisi
}

\author{
Kamil Emre GERÇEKASLAN ${ }^{1}$, Hüseyin BOZ ${ }^{2}$
}

ÖZET: Bu çalışmanın amacı keçiboynuzu ununun kakaolu kekin fiziksel, duyusal ve tekstürel özelliklerine etkilerini değerlendirmektir. Kek formülasyonundaki kakao yerine \%0-20-40-60 ve 80 oranlarında keçiboynuzu unu kullanılmış ve ilave edilen keçiboynuzu unu miktarı kakao miktarından düşülmüştür. Keçiboynuzu unu ilavesi kek örneklerinin $\mathrm{L}$, a ve b renk değerlerini $\mathrm{p}<0.01$ düzeyinde etkilemiştir. Keçiboynuzu unu ilavesi kek örneklerinin hacim ve spesifik hacim değerlerini olumsuz etkilememiş, kül içeriğini ise kontrole kıyasla önemli $(\mathrm{p}<0.01)$ düzeyde düşürmüştür. Yapılan duyusal değerlendirmelerde bütün formülasyonlar panelistler tarafından kabul görmüş olsa da kontrol kek örneğine en yakın skorları sırasıyla \%20 ve \%40 keçiboynuzu unu içeren formülasyonlar almıştır. Tekstür analizinden elde sonuçlara göre keçiboynuzu unu ilavesi kek örneklerinin kohesivliğini artırmış; sertlik, çiğnenebilirlik ve elastikiyet değerlerinde özellikle \%40 keçiboynuzu unu seviyesine kadar olumsuz bir etki oluşturmadığı gözlemlenmiştir. Bu sonuçlar 1şığında keçiboynuzu ununun kakaolu kek üretiminde \%40 seviyesine kadar kullanılabileceği ifade edilebilir.

Anahtar Kelimeler: Kek, keçiboynuzu unu, kakao, tekstür

\section{The Effect of Carob Flour on the Physical, Sensory and Textural Properties of Cocoa Cake}

\begin{abstract}
The aim of this study was to evaluate the effect of carob flour on physical, sensory and textural properties of cocoa cakes. Instead of cocoa in the cake formulation, 0-20-40-60 and 80\% of carob flour was used and the amount of carob flour added was subtracted from the amount of cocoa. Carob flour affected L, a and b color values of crust color of cake samples statistically at $\mathrm{p}<0.01$ level. The addition of carob flour did not adversely affect the volume and specific volume values of the cakes, but reduced the ash content of the cake samples at a significant $(\mathrm{p}<0.01)$ level compared to the control. If all the formulations in the sensory evaluations were accepted by the panelists, the closest scores to the control cake sample were formulations containing 20 and $40 \%$ carob flour, respectively. According to the results obtained from the texture analysis, the addition of carob flour increased the cohesiveness of the cake samples and it was observed that the hardness, chewiness and elasticity values did not cause a negative effect until the level of carob flour was $40 \%$. These results suggest that carob flour can be used up to $40 \%$ in the production of cocoa cake.
\end{abstract}

Keywords: Cake, carob flour, cocoa, texture

\footnotetext{
Kamil Emre GERÇEKASLAN (0000-0002-9804-9982), Hacı Bektaş Veli Üniversitesi, Mühendislik Fakültesi, Gıda Mühendisliği, Nevşehir, Turkey

Hüseyin BOZ (0000-0003-1846-5589), Atatürk Üniversitesi, Turizm Fakültesi, Gastronomi ve Mutfak Sanatları, Erzurum, Turkey Sorumlu yazar/Corresponding Author: Hüseyin BOZ, huseyinboz@atauni.edu.tr
} 


\section{GİRiş}

Kek; hazırlanışı kolay, maliyeti düşük ve özellikle raf ömrünün oldukça uzun olması nedeniyle gerek yetişkinler gerekse çocuklar tarafından yaygın bir şekilde tüketilen tahıl ürünleri arasındadır.

Kakao; yüksek yağ ve hidrofobik polisakkarit içeriğiyle çikolata, kek, bisküvi ve çeşitli tatlılarda yaygın olarak kullanılmaktadır (Omobuwajo et al., 2000). Günümüzde kakao yerine keçiboynuzu unu kullanımı bu ürünlerde gerek yağ içeriğini azaltmak gerekse ürünlerin fonksiyonel özelliklerini iyileştirmek maksadıyla tercih edilmektedir (Rosa et al., 2015).

Keçiboynuzu (Ceratonia siliqua L.) Leguminoseae (Fabaceae-Baklagiller) familyasının Caesalpinaceae alt familyasına ait olan, antik çağlardan bugüne dek var olan, hem çevresel hem de ekonomik olarak önem taşıyan bir bitkidir. Kök yapısı sayesinde yetiştiriciliğinin yapıldığı alanlarda erozyon gibi afetleri önleyebildiği ifade edilen keçiboynuzunun Dünyada çoğunlukla Akdeniz iklimine sahip alanlarda, İspanya, İtalya, Fas, Portekiz, Yunanistan, Kıbrıs ve Türkiye gibi ülkelerde yetiştiriciliğinin yapıldı ğı ifade edilmektedir (Pazır ve Alper, 2016).

Keçiboynuzu unu; ekmek, makarna, kek ve erişte gibi fırın ürünlerinde besin içeriğini zenginleştirmek (Ortega et al., 2011; Turfani et al., 2017), çölyak hastaları için üretilen gıdalarda ise yapı düzenleyici olarak kullanılmaktadır (Feillet and Roulland, 1998; Durazzo et al., 2014).

Keçiboynuzu meyvesi yüksek düzeydeki çözülebilir şeker $\left(40-50 \mathrm{~g} 100 \mathrm{~g}^{-1}\right)$, düşük protein

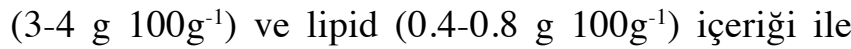
karakterize edilen bir meyvedir. Ancak diyet lifi, fenolik bileşenler, vitamin ve mineral bakımından oldukça zengin olması (Kumazawa et al., 2002; Khlifa et al., 2013; Biernacka et al., 2017), keçiboynuzuna olan ilgiyi her geçen gün artırmakta ve diğer birçok endüstride olduğu gibi gıda endüstrisinde de kullanım alanını genişletmektedir.

Gıda endüstrisinde çekirdeksiz keçiboynuzu meyvesinin un haline getirilerek kakao yerine kullanılabileceği (Durazzo et al., 2014), keçiboynuzu ununun gıda üretimi için fonksiyonel bir katkı olarak değerlendirilebileceği belirtilmektedir (Tsatsaragkou et al., 2014; Biernacka et al., 2017). Fonksiyonel bir bileşen olarak kabul edilen keçiboynuzu ununun kek formülasyonlarına ilave edilmesi şüphesiz kekin gerek besin değerini, gerekse fonksiyonel özelliklerini artıracaktır. Ancak keçiboynuzu unu kullanımının kekin fiziksel, tekstürel ve tüketici tercihlerini birinci derecede etkileyen duyusal özelliklerini nasıl etkileyeceği bilinmemektedir. Bu çalışmada kek üretiminde formülasyona kakao yerine farklı oranlarda keçiboynuzu unu ilavesinin kek örneklerinin fiziksel, tekstürel ve duyusal özelliklerine etkilerini belirlemek amaçlanmıştır.

\section{MATERYAL VE YÖNTEM}

\section{Materyal}

Kek üretiminde kullanılan un, şeker, yağ, kakao, keçiboynuzu unu ve kabartma tozu Nevşehir'de yerel bir marketten satın alınmıştır. Üretimde kullanılan un $\% 12.80$ nem, $\% 0.495$ kül, $\% 11.49$ protein ve $\% 29$ yaş gluten; keçiboynuzu unu \%6.26 nem, \%3.20 kül ve kakao \% 3.71 nem ve \%12.80 kül içeriğine sahiptir.

\section{Kek Üretimi}

Kek üretiminde Karaoğlu ve ark, (2008) tarafından tarif edilen formülasyon ve pişirme işlemi kullanılmıştır. Bu çalışmada farklı olarak, kakaolu kek üretimi için ön denemelerle belirlenen bir değer olarak formülasyona $\% 10$ kakao eklenmiştir. Formülasyondaki kakao \%20, 40,60 ve 80 oranlarında keçiboynuzu unu ile ikame edilmiştir. Kontrol kek örneklerine keçiboynuzu unu ilave edilmemiş, formülasyonlarda \%10 kakao kullanılmıştır. Kek hamuru hazırlanırken bileşenlerin karıştırılmasında Karaoğlu ve ark, (2008) tarafından verilen sira takip edilmiştir. Kenwood (KM-242) marka mikser kullanılarak öncelikle yumurta akı ve tuz 4 dakika, şeker ilave edilerek 1 dakika, süt ilave edilerek 2 dakika, yağ ve yumurta sarısı edilerek 1 dakika 5 . devirde ve son olarak un, kakao ve kabartma tozu ilave edilerek 4. devirde 4 dakika karıştırılmıştır. Elde edilen kek hamurları muffin kek kalıplarına 60'ar g olacak şekilde konulmuş, bir elektrikli fırında (Arçelik MF44) $175^{\circ} \mathrm{C}$ 'de 35 dakika süre ile pişirilmiştir.

\section{Keklerde Yapılan Analizler}

Materyallerin ve kek örneklerinin nem ve kül içerikleri sırasıyla AACC metot 44-15.02 ve 08-01.01'e göre yapılmıştır (AACC, 2003). Üretilen 
kekler oda sıcaklığında 1 saat bekletilip soğutulduktan sonra tartılmış, kolza tohumu kullanılarak yer değiştirme esasına göre hacimleri ve spesifik hacimleri belirlenmiştir (Elgün ve ark., 1999). Keklerin kabuk ve iç rengi ölçümlerinde Konica Minolta (CR-400) Colorimeter (Minolta Camera Co., Osaka, Japan) kullanılmıştır (Elgün ve ark., 1999).

\section{Tekstür Analizleri}

Keçiboynuzu unu ilave edilerek üretilen kek örneklerinde tekstür analizleri TA-XT Plus tekstür analiz cihazında (Stable Micro Systems, Godalming, Surrey, UK) 100 mm'lik prob (P-100) kullanılarak gerçekleştirilmiştir. Pişirilip oda sıcaklığında soğutulduktan sonra streç filmle kaplanmış, yaklaşık 24 saat bekletilmiş keklerden tekstür analizi için silindir sonda yardımıyla $3 \mathrm{~cm}$ çapında ve $3 \mathrm{~cm}$ yüksekliğinde örnekler çıkartılmıştır. TPA metodunun parametreleri; test öncesi hız $1 \mathrm{~mm} \mathrm{~s}^{-1}$, test hizı $2 \mathrm{~mm} \mathrm{~s}^{-1}$, test sonrası hız $1 \mathrm{~mm} \mathrm{~s}^{-1}$, bekleme süresi $5 \mathrm{~s}$, tetikleyici kuvvet $10 \mathrm{~g}$ (otomatik) ve sıkıştırma oranı \%40 olarak ayarlanmıştır. Bu şartlar altında çizdirilen grafikten sertlik, elastikiyet, kohesivlik ve çiğnenebilirlik değerleri hesaplanmıştır (Karaoğlu ve ark., 2008).

\section{Duyusal Analiz}

Kek örneklerinin duyusal analizleri Hacı Bektaş Veli Üniversitesi, Gıda Mühendisliği bölümü-Genel Uygulama Laboratuvarında yapılmış, panelistler bay ve bayan olmak üzere Gıda Mühendisliği bölümü akademik personeli ve yüksek lisans öğrencilerinden seçilmiştir. Üretilen kek örnekleri dört eşit parçaya bölünerek, her biri rastgele üç haneli rakamlar olacak şekilde kodlanarak tabaklarda içme suyu eşliğinde 10 paneliste sunulmuş ve duyusal olarak değerlendirmeleri istenmiştir. Kek örnekleri kabuk rengi, iç renk, tat ve genel kabul edilebilirlik özellikleri açısından değerlendirmeye tabi tutulmuşlardır. Parametrelerin değerlendirilmesinde 9 puanlı hedonik skala (1=çok kötü, $9=$ çok iyi) kullanılmış ve panelistlerden her kek örneği için birden dokuza kadar puanlar vermeleri istenmiştir.

\section{İstatistiksel Analiz}

Keçiboynuzu unu \%0-20-40-60 ve \%80 olmak üzere beş farklı düzeyde kullanılmıştır. İlave edilen keçiboynuzu unu miktarı, formülasyondaki kakao miktarından düşülmüştür. Beş farklı formülasyonda hazırlanan deneme 3 tekerrürlü olarak yürütülmüştür. Araştırma neticesinde elde edilen veriler SPSS 22.0 paket programı ile Duncan Çoklu Karşılaştırma Testine tabi tutularak karşılaştırılmıştır. İstatistiksel analizler neticesinde aralarındaki farklılıklar 0.05 güven aralığına göre önemli bulunan değerler Çizelge ve Grafiklerde farklı harflerle gösterilmiştir. Bütün değerler ortalama \pm standart hata olarak sunulmuştur.

\section{BULGULAR VE TARTIŞMA}

Keçiboynuzu ununun kekin bazı kimyasal ve fiziksel özelliklerine etkisi Çizelge 1'de verilmiştir. Elde edilen sonuçlara göre keçiboynuzu unu kekin kül içeriği hariç diğer özelliklerini $\mathrm{p}<0.05$ düzeyinde etkilemiştir. Kek örneklerinin nem içeriğinde artış, örneklerin kül içeriğinde ise formülasyona ilave edilen keçiboynuzu unu miktarındaki artışa bağlı olarak önemli düzeyde azalma gözlenmiştir. Kek örneklerinin kül içeriğindeki bu azalmanın sebebi olarak kül içeriği daha yüksek (\%12.80) olan kakaonun formülasyondan çekilip yerine kül içeriği kakaoya kıyasla daha düşük (\%3.20) olan keçiboynuzu ununun dâhil edilmesi gösterilebilir. Kek örneklerinin nem içeriğindeki artışın nedeni olarak da keçiboynuzu ununun diyet lifi içeriği gösterilebilir. Zira diyet lifin ürünlerde suyu tutabilen en önemli bileşenlerden birisi olduğu bildirilmektedir (Padilha et al., 2010).

Kek örneklerinin hacim ve spesifik hacim değerlerinde keçiboynuzu unu ilavesinin olumsuz bir etki oluşturmadığı gözlemlenmiştir. Fırın ürünlerinde spesifik hacim en önemli kalite kriterlerinden biridir. Keçiboynuzu ilavesi kek örneklerinin spesifik hacimlerinde herhangi bir olumsuzluk oluşturmamış, aksine kek örneklerinin spesifik hacim değerlerini önemli düzeyde artırmıştır.

En düşük spesifik hacim $\% 0$ keçiboynuzu içeren kontrol kekte belirlenmiş, keçiboynuzu ilave edilen formülasyonların tamamında spesifik hacim değerleri kontrol kekten yüksek çıkmıştır. Benzer sonuçlar glutensiz ekmek üretiminde Tsatsaragkou et al (2017) tarafından elde edilmiş, ekmek üretiminde keçiboynuzu unu ilavesiyle ekmeklerin spesifik hacimleri artış göstermiş ve bu durum keçiboynuzu unundaki hidrokolloidlerin hamur formülasyonundaki diğer bileşenler ile reaksiyonlarından kaynaklanabileceği ifade edilmiştir. 
Çizelge 1. Keçiboynuzu ununun kekin bazı kimyasal ve fiziksel özelliklerine etkisi ${ }^{\mathrm{a}}$

\begin{tabular}{cccccc}
\hline $\begin{array}{c}\text { Keçiboynuzu unu } \\
(\%)\end{array}$ & Nem(\%) & Kül $(\% \mathbf{K M})$ & Hacim $\left(\mathbf{c m}^{\mathbf{3}}\right)$ & $\begin{array}{c}\text { Spesifik hacim } \\
\left(\mathbf{c m}^{\mathbf{3}} \mathbf{g}^{-1}\right)\end{array}$ & Pişme kaybı $(\%)$ \\
\hline 0 & $26,98 \pm 0.34 \mathrm{~b}$ & $1.50 \pm 0.02 \mathrm{a}$ & $105.3 \pm 0.66 \mathrm{~b}$ & $2.03 \pm 0.02 \mathrm{c}$ & $13.23 \pm 0.36 \mathrm{~b}$ \\
20 & $27.02 \pm 0.13 \mathrm{~b}$ & $1.38 \pm 0.01 \mathrm{~b}$ & $108.0 \pm 0.00 \mathrm{a}$ & $2.09 \pm 0.01 \mathrm{a}$ & $14.16 \pm 0.13 \mathrm{a}$ \\
40 & $27.62 \pm 0.09 \mathrm{a}$ & $1.31 \pm 0.01 \mathrm{c}$ & $106.0 \pm 0.01 \mathrm{~b}$ & $2.05 \pm 0.01 \mathrm{bc}$ & $14.06 \pm 0.08 \mathrm{a}$ \\
60 & $26.91 \pm 0.06 \mathrm{~b}$ & $1.20 \pm 0.01 \mathrm{~d}$ & $107.3 \pm 0.66 \mathrm{a}$ & $2.08 \pm 0.01 \mathrm{ab}$ & $14.17 \pm 0.03 \mathrm{a}$ \\
80 & $26.71 \pm 0.08 \mathrm{~b}$ & $1.14 \pm 0.00 \mathrm{e}$ & $108.0 \pm 0.00 \mathrm{a}$ & $2.10 \pm 0.00 \mathrm{a}$ & $14.32 \pm 0.03 \mathrm{a}$ \\
$\mathrm{P}$ & $*$ & $* *$ & $*$ & $*$ & $*$ \\
\hline
\end{tabular}

a: Aynı sütunda aynı harfle gösterilen ortalamalar istatistiksel olarak birbirinden farksızdır.

Herhangi bir gıdanın rengi gıdanın kalitesini gösteren en önemli parametrelerden biridir (Biernacka et al., 2017). Renk aynı zamanda tüketici tercihlerini belirleyen unsurlar arasında birinci sirada yer almaktadır.

Çizelge 2'deki veriler incelendiğinde keçiboynuzu ununun kek örneklerinin kabuk rengi L, a ve b renk değerlerini $\mathrm{p}<0.01$ çok önemli düzeyde etkilediği görülmektedir.

Kek örneklerinin kabuk rengi L değerleri 22.7 ile 30.9 arasında değişiklik göstermiş, en düşük kabuk rengi $\mathrm{L}$ değeri kontrolde, en yükssek $\mathrm{L}$ değeri ise $\% 80$ keçiboynuzu unu ilavesinde gözlemlenmiştir. Bir başka ifadeyle formülasyonlarda keçiboynuzu unu ilavesi arttıkça kek örneklerinin kabuk renginde açılma meydana gelmektedir.
Keçiboynuzu unu ilavesi kabuk rengi a ve b değerlerini de artırıcı yönde etkilemiş, formülasyondaki keçiboynuzu unu artışına paralel olarak a ve b renk değerleri artış göstermiştir. Kabuk renginde olduğu gibi kek örneklerinin iç renk L, a ve b değerlerinde de keçiboynuzu unu ilavesiyle bir artış gözlenmiştir. Formülasyonlara renk olarak daha yoğun olan kakao yerine keçiboynuzu unu dâhil edildiğinden kek örneklerindeki renk değişiminin bu yönde olması normaldir.

Renk değerleri için benzer sonuçlar; soya ve muz unu kullanılarak üretilen keklerde kakao yerine keçiboynuzu ununun kullanıldı $\breve{g} ı$ bir çalışmada da elde edilmiş, keçiboynuzu unu ilavesiyle kek örneklerinin $\mathrm{L}$ ve a renk değerlerinin arttı̆̆ bildirilmiştir (Rosa et al., 2015).

Çizelge 2. Keçiboynuzu ununun kek örneklerinin kabuk rengi ve iç renk değerlerine etkisia

\begin{tabular}{ccccccc}
\hline & \multicolumn{3}{c}{ Kabuk rengi } & & \multicolumn{2}{c}{ Iç renk } \\
\hline $\begin{array}{c}\text { Keçiboynuzu } \\
\text { unu (\%) }\end{array}$ & $\mathbf{L}$ & $\mathbf{a}$ & $\mathbf{b}$ & $\mathbf{L}$ & $\mathbf{a}$ & $\mathbf{b}$ \\
\hline 0 & $22.7 \pm 0.72 \mathrm{e}$ & $6.92 \pm 0.06 \mathrm{e}$ & $5.78 \pm 0.06 \mathrm{e}$ & $21.96 \pm 0.23 \mathrm{e}$ & $7.08 \pm 0.15 \mathrm{~b}$ & $6.94 \pm 0.15 \mathrm{e}$ \\
20 & $24.3 \pm 0.10 \mathrm{~d}$ & $7.68 \pm 0.06 \mathrm{~d}$ & $6.79 \pm 0.07 \mathrm{~d}$ & $24.30 \pm 0.22 \mathrm{~d}$ & $7.67 \pm 0.06 \mathrm{a}$ & $8.08 \pm 0.16 \mathrm{~d}$ \\
40 & $25.6 \pm 0.02 \mathrm{c}$ & $8.62 \pm 0.10 \mathrm{c}$ & $7.79 \pm 0.20 \mathrm{c}$ & $27.47 \pm 0.20 \mathrm{c}$ & $7.88 \pm 0.16 \mathrm{a}$ & $8.99 \pm 0.28 \mathrm{c}$ \\
60 & $27.4 \pm 0.10 \mathrm{~b}$ & $9.25 \pm 0.09 \mathrm{~b}$ & $9.19 \pm 0.04 \mathrm{~b}$ & $30.13 \pm 0.22 \mathrm{~b}$ & $8.02 \pm 0.06 \mathrm{a}$ & $10.15 \pm 0.04 \mathrm{~b}$ \\
80 & $30.9 \pm 0.28 \mathrm{a}$ & $10.80 \pm 0.03 \mathrm{a}$ & $12.31 \pm 0.17 \mathrm{a}$ & $35.85 \pm 0.84 \mathrm{a}$ & $7.70 \pm 0.02 \mathrm{a}$ & $11.64 \pm 0.12 \mathrm{a}$ \\
$\mathrm{P}$ & $* *$ & $* *$ & $* *$ & $* *$ & $*$ & $* *$
\end{tabular}

a: Aynı sütunda aynı harfle gösterilen ortalamalar istatistiksel olarak birbirinden farksızdır. 
Bir gıdanın besin içeriği ne kadar yüksek olursa olsun eğer gıdanın duyusal özellikleri kabul görmezse tüketiciler tarafından tercih edilmemektedir. Çünkü tüketiciler genel olarak gıdanın önce duyusal özelliklerine bakarak tercihte bulunmaktadırlar (Yousif et al., 2012). Keçiboynuzu unu ilave edilerek üretilen kek örneklerinin yapılan duyusal değerlendirmede panelistler tarafından kabul gördüğü Çizelge 3'deki verilerden anlaşılmaktadır. Genel olarak kek formülasyonlarındaki keçiboynuzu unu artışına bağ olarak panelistlerin beğenisi azalmış, beğenideki bu azalma \% 60 ve 80 keçiboynuzu unu ilavesinde belirgin olarak gözlemlenmiştir. Duyusal analizlerde en yüksek skorları kontrol kek, kontrol keke en yakın değerleri ise sirasiyla $\% 20$ ve 40 keçiboynuzu unu içeren formülasyonlar almıştır. \%60 ve 80 keçiboynuzu unu içeren formülasyonlar ise çok düşük skorlar almasa da en az beğenilen formülasyonlar olmuştur.

Çizelge 3. Keçiboynuzu ununun kek örneklerinin duyusal özelliklerine etkisi ${ }^{\mathrm{a}}$

\begin{tabular}{ccccc}
\hline $\begin{array}{c}\text { Keçiboynuzu } \\
\text { unu (\%) }\end{array}$ & Kabuk rengi & İç renk & Tat & Genel kabul edilebilirlik \\
\hline 0 & $9.3 \pm 0.33 \mathrm{a}$ & $9.3 \pm 0.33 \mathrm{a}$ & $8.3 \pm 0.33 \mathrm{a}$ & $7.3 \pm 0.33 \mathrm{a}$ \\
20 & $9.3 \pm 0.33 \mathrm{a}$ & $9.0 \pm 0.57 \mathrm{a}$ & $7.6 \pm 0.33 \mathrm{~b}$ & $7.0 \pm 0.00 \mathrm{a}$ \\
40 & $8.3 \pm 0.33 \mathrm{~b}$ & $8.3 \pm 0.33 \mathrm{a}$ & $6.0 \pm 0.00 \mathrm{~d}$ & $7.0 \pm 0.00 \mathrm{a}$ \\
60 & $7.0 \pm 0.00 \mathrm{c}$ & $7.0 \pm 0.00 \mathrm{~b}$ & $6.0 \pm 0.00 \mathrm{~d}$ & $6.6 \pm 0.33 \mathrm{a}$ \\
80 & $6.0 \pm 0.00 \mathrm{~d}$ & $5.0 \pm 0.00 \mathrm{c}$ & $7.0 \pm 0.00 \mathrm{c}$ & $6.0 \pm 0.00 \mathrm{~b}$ \\
$\mathrm{P}$ & $* *$ & $* *$ & $* *$ & $*$ \\
\hline
\end{tabular}

a: Aynı sütunda aynı harfle gösterilen ortalamalar istatistiksel olarak birbirinden farksızdır.

Keçiboynuzu unu ilavesinin kek örneklerinin tekstürel özelliklerine etkisi Şekil 1'de görülmektedir. Keçiboynuzu unu ilavesi kek örneklerinin tekstürel özelliklerini genel olarak $\mathrm{p}<0.05$ düzeyinde etkilemiştir. Tüketicilerin tazelik algısı ile yakından alakalı olması nedeniyle fırın ürünlerinin değerlendirilmesinde gıdanın sertliği en dikkat çeken tekstürel özellikler arasındadır (Giannou and Tzia 2007; Karaoğlu ve ark., 2008). Kek örneklerinin sertlik değerleri \%20 ve 40 keçiboynuzu unu ilavesiyle istatistiksel olarak anlamlı bir değişiklik oluşturmamış; \%60 ve 80 keçiboynuzu unu ilavesiyle örneklerin sertlik değerleri kısmen azalmış olsa da önemli düzeyde bir değişiklik göstermemiştir (Şekil 1A). En düşük sertlik değeri \%60 keçiboynuzu unu içeren formülasyonda, en yüksek sertlik değerleri ise keçiboynuzu unu içermeyen kontrol formülasyonunda belirlenmiştir. Keçiboynuzu unu ilavesiyle kek örneklerinin sertlik değerlerinin azalması örneklerin su içeriğiyle ilişkilendirilebilir. Çünkü keçiboynuzu unu ilavesiyle örneklerin nem içeriği artmış ve bu artışın doğal bir sonucu olarak örneklerin sertliği azalmıştır.
Elastikiyet; fırın ürünlerinde birinci sıkıştırmadan sonra gıdanın eski halini ne düzeyde aldığını gösteren bir parametredir ve genel olarak yüksek olması arzu edilmektedir (Gupta et al., 2007). Üretilen kek örneklerinin elastikiyet değerleri 0.931 ile 0.939 arasında değişiklik göstermiştir (Şekil 1B). En düşüik elastikiyet değerlerine \%40 keçiboynuzu unu içeren formülasyonda, en yüksek elastikiyet değerlerine ise kontrol kek örneklerinde ulaşılmıştır. Keçiboynuzu unu kek örneklerinin elastikiyet değerlerinde istatistiksel olarak anlamlı bir değişiklik oluşturmamıştır. Bir başka ifadeyle keçiboynuzu ununun kek örneklerinin elastikiyetini olumsuz olarak etkilemediği de söylenebilir. Rosa et al., (2015) tarafından yapılan çalışmada soya ve muz unu kullanılarak üretilen keklerde kakao yerine keçiboynuzu unu kullanıldığında örneklerin elastikiyet değerleri artış göstermiştir. Oysa bizim çalışmamızda istatistiksel olarak anlamlı bir değişiklik oluşturmasa da kakao yerine kek formülasyonlarına keçiboynuzu unu ilavesi örneklerin elastikiyet değerlerini düşürmüştür. 




Şekil 1. Keçiboynuzu ununun kek örneklerinin tekstürel özelliklerine etkisi

Kohesivlik gıda bileşenlerinin birbirinde ne düzeyde tutunduğunu ya da gıdanın bütünlüğünü ifade eden bir tekstürel parametredir. Fırın ürünleri bileşenlerinin moleküler interaksiyonu ile ilişkili olan kohesivlik değerlerinin düşük olması ürünün tutulması ve dilimlenmesinin zorluğuna işaret eder (Esteller et al., 2006, Rosa et al., 2015). Şekil 1C'de genel olarak keçiboynuzu unu ilavesinin kek örneklerinin kohesivlik değerlerini artırdığı görülmektedir. Keçiboynuzu unu ilavesi örneklerin kohesivliğini de olumsuz etkilememiş, aksine kek bileşenlerinin bütünlüğünü yâda bileşenlerin birbirine tutunmalarını artırmıştır.

Fiziksel olarak katı bir ürünün parçalarına ayrılıp yutmaya hazır hale getirebilmek için gerekli olan enerji olarak tanımlanan çiğnenebilirlik, gıdanın yutmaya hazır hale getirilinceye kadar gerekli olan çiğneme sayısı olarak da ifade edilmektedir (Karaoğlu, 2010; Ansari et al., 2014). Kek örneklerinin çiğnenebilirlik değerlerinde özellikle \%40 keçiboynuzu unu seviyesine kadar anlamlı bir değişiklik olmadığı Şekil 1D'de görülmektedir. En yüksek çiğnenebilirlik değeri kontrol grubu keklere ait iken en düşük çiğnenebilirlik değeri \%60 keçiboynuzu unu ilave edilen örneklere aittir. \%20 ve 40 keçiboynuzu unu ilavesinin kek örneklerinde çiğnenebilirlik açısından olumsuz bir etki oluşturmadığı gözlemlenmiştir. Kek örneklerinin çiğnenebilirlik değerlerinde istatistiksel olarak anlamlı bir fark çıkmasa da genel itibariyle keçiboynuzu unu kullanımının, keklerin çiğnenebilirlik değerlerini düşürdüğü gözlemlenmiştir. Buradan yola çıarak keçiboynuzu unu ilavesinin keklerin yenilebilirliğini kolaylaştırdığı sonucuna varmak mümkündür. 


\section{SONUÇ}

Araştırma neticesinde elde edilen bulgulara göre keçiboynuzu unu ilavesi kek örneklerinin hacim ve spesifik hacim değerlerini olumsuz etkilememiş, kek örneklerinin kül içeriğini ise kontrole kıyasla önemli düzeyde düşürmüştür. Yapılan duyusal analizlerde en yüksek skorları kontrol kek, kontrol keke en yakın skorları ise sırasıyla $\% 20$ ve 40 keçiboynuzu unu içeren formülasyonlar almıştır. Kek örneklerinin L, a ve b renk

\section{KAYNAKLAR}

AACC, 2003. Approved methods of the American association of cereal chemists (10th ed.). St. Paul, MN: The Association.

Ansari S, Maftoon-Azad N, Farahnaky A, Hosseini E, Badii F, 2014. Effect of moisture content on textural attributes of dried figs. International Agrophysics, 28: 403-412.

Biernacka B, Dziki D, Gawlik-Dziki U, Różyło R, Siastała M, 2017. Physical, sensorial, and antioxidant properties of common wheat pasta enriched with carob fiber. LWT - Food Science and Technology, 77:186-192.

Durazzo A, Turfani V, Narducci V, Azzini E, Maiani G, Carcea M, 2014. Nutritional characterisation and bioactive components of commercial carobs flours. Food Chemistry, 153:109-113.

Elgün A, Ertugay Z, Certel M, Kotancılar, HG, 1999. Tahıl Ürünlerinde Analitik kalite Kontrolü ve Laboratuvar Uygulama Kılavuzu. Atatürk Üniversitesi, Ziraat Fakültesi Yayınları, Yayın No: 335, Erzurum. 245s.

Esteller MS, Zancanaro O, Lannes SCS, 2006. Bolo de "chocolate" produzido com pó de cupuaçu e kefir. Revista Brasileira de Ciências Farmacêuticas, 42(3): 447-454.

Feillet P, Roulland T M, 1998. Caroubin: A gluten-like protein isolate from carob bean germ. Cereal Chemistry, 75: 488-492.

Giannou V, Tzia C, 2007. Frozen dough bread: Quality and textural behavior during prolonged storage - Prediction of final product characteristics. Journal of Food Engineering, 79: 929-934.

Gupta RK, Sharma A, Sharma R, 2007. Instrumental texture profile analysis (TPA) of shelled sunflower seed caramel snack using response surface methodology. Food Science and Technology International, 13(7): 455-46.

Karaoğlu MM, 2010. Yusufeli'nde üretilen pekmez, pestil ve kömelerin dokusal özellikleri. Geçmişten Geleceğe Yusufeli Sempozyumu, 10-12 Haziran 2010, Yusufeli/Artvin.

Karaoğlu MM, Kotancılar HG, Gerçekaslan KE, 2008. The effect of par-baking and frozen storage time on the quality of cup cake. International Journal of Food Science and Technology, 43: 1778-1785.

Khlifa M, Bahloul A, Kitane S, 2013. Determination of chemical composition of carob pod (Ceratonia siliqua L.) and its morphological study. Journal of Materials and Environmental Science, 4: 348-353. değerleri ise genel olarak keçiboynuzu unu ilavesiyle artış göstermiştir. Tekstür analizlerinden elde sonuçlara göre keçiboynuzu unu ilavesinin kek örneklerinin kohesivliğini artırdığı, sertlik, çiğnenebilirlik ve elastikiyet değerlerinde özellikle \%40 keçiboynuzu unu seviyesine kadar olumsuz bir etki oluşturmadığ 1 gözlemlenmiştir. Bu sonuçlar işığında keçiboynuzu ununun kakaolu kek üretiminde \%40 seviyesine kadar kullanılabileceği ifade edilebilir.

Kumazawa SHK, Taniguchi MASAT, Suzuki, YAS, Shimura MAS, Kwon MIUNK, Nakayama TSN, 2002. Antioxidant activity of polyphenols in carob pods. Journal of Agricultural and Food Chemistry, 50: 373-377.

Omobuwajo TO, Busari OT, Osemwegie AA, 2000. Thermal agglomeration of chocolate drink powder. Journal of Food Engineering, 46(2): 73-81.

Ortega N, Macià A, Romero M-P, Reguant J, Motilva M-J, 2011. Matrix composition effect on the digestibility of carob flour phenols by an in-vitro digestion model. Food Chemistry, 124(1): 65-71.

Padilha V, Rolim PM, Salgado SM, Livera A, Andrade SA, Guerra N, 2010. Perfil sensorial de bolos de chocolate formulados com farinha de yacon (smallanthus sonchiflus). Ciência e Tecnologia de Alimentos, 30(3): 735-740.

Pazır F, Alper Y, 2016. Keçiboynuzu meyvesi (Ceratonia siliqua L.) ve sağlık. Akademik Gıda, 14(3): 302-306.

Rosa CS, Tessele K, Prestes RC, Silveira, M, Franco F, 2015. Effect of substituting of cocoa powder for carob flour in cakes made with soy and banana flours. International Food Research Journal 22(5): 2111-2118.

Tsatsaragkou K, Gounaropoulos G, Mandala I, 2014. Development of gluten free bread containing carob flour and resistant starch. LWT - Food Science and Technology, 58: 124-129.

Tsatsaragkou K, Kara T, Ritzoulis C, Mandala I, 20017. Improving carob flour performance for making gluten-free breads by particle size fractionation and jet milling. Food and Bioprocess Technology, 10(5): 831-841.

Turfani V, Narducci V, Durazzo A, Galli V, Carcea M, 2017. Technological, nutritional and functional properties of wheat bread enriched with lentil or carob flours. LWT - Food Science and Technology, $78: 361-366$.

Yousif EI, Gadallah MGE, Sorour A, 2012. Physico-chemical and rheological properties of modified corn starches and its effect on noodle quality. Annals of Agricultural Science, 57(1):1927. 